\title{
Operative details after laparoscopic distal pancreatectomy: our experiences in a tertiary center
}

\section{Laparoskopik distal pankreatektomi operasyon sonuçları: 3.basamak merkez deneyimlerimiz}

\author{
Hacı Murat Çaycı ${ }^{1}$, Umut Eren Erdoğdu ${ }^{1}$, Evren Dilektaşlı ${ }^{1}$, Hasan Çantay ${ }^{1}$, Muhammed \\ Doğangün ${ }^{1}$, Hüseyin Ayhan Kayaoğlu ${ }^{1}$ \\ ${ }^{1}$ T.C. Sağlık Bilimleri Üniversitesi Bursa Yüksek İhtisas Eğitim ve Araştırma Hastanesi, Genel Cerrahi Kliniği, Bursa, \\ Türkiye
}

Dergiye Ulaşma Tarihi: 24.02.2017 Dergiye Kabul Tarihi: 22.03.2017Doi: 10.5505/aot.2017.98250

\section{ÖZET}

GíRIŞ ve AMAÇ: Minimal invaziv cerrahi pankreas cerrahisinde giderek artan sıklıkta kullanılmaktadır. Çalışmamızda laparoskopik distal pankreatektomi operasyon deneyimi ve erken dönem sonuçlarımızın sunulması amaçlanmış̧ır.

YÖNTEM ve GEREÇLER: Pankreas gövde ve kuyruk yerleşimli tümoral lezyonlar nedeniyle laparoskopik distal pankreatektomi yapılan 15 hastanın verileri retrospektif olarak değerlendirildi. Hastaların demografik verileri, comorbidite, lezyon özellikleri, cerrahi sonuçlar ve uzun dönem takip sonuçları kaydedildi. BULGULAR: Laparoskopik distal pankreatektomi yapılan olguların 7'si erkek $(\% 46,6), 8$ 'i kadın $(\% 53,3)$ idi. Olguların yaş ortalaması $60,4 \pm 9,82$ idi. Tümor çapı median 40,4 (30-70) mm saptandı. Ortalama çıkarılan lenf nodu $6(2-12)$ saptandi. Konversiyon laparatomi $6(\% 40)$ hastada vasküler invazyon veya hemoraji sonrasında uyguland. Postoperatif dönemde $2(\% 13,3)$ hastada Grade A pankreas fistülü gelişti ve takip süresince spontan kapandı. Ortalama takip süresi 22 aydı (12-36 ay). Takip döneminde duktal adenokarsinomu olan $1(\% 9,09)$ hasta 14. Ayda uzak metastaz nedeniyle eks oldu.

TARTIŞMA ve SONUÇ: Pankreas gövde ve kuyruk yerleşimli bening ve malign lezyonu olan hastalarda laparoskopik distal pankreatektomi klasik cerrahi girişimlere alternatif olabilir.

Anahtar Kelimeler: Pankreas, kanser, laparoskopi, distalpankreatektomi

\begin{abstract}
INTRODUCTION: Minimal invasive surgery is being increasing lyused in pancreas surgery. In this study, we aimed to present our laparoscopic distal pancreatectomy experience.

METHODS: Data from 15 patients who underwent laparoscopic distal pancreatectomy (LDP) due to tumoral lesions of the pancreas, located in the body and tail were retrospectively evaluated. Demographic data, comorbidity, lesion characteristics, surgical out come and long term follow-up results were recorded. RESULTS: There were 7 males (46.6\%) and 8 females (53.3\%) with theme an age of $60.4 \pm 9.82$ in the study. Mean tumor diameter was 40.4 (30-70) $\mathrm{mm}$ and mean derived lymph nodes was 6 (2-12). Conversion laparotomy was necessary in $6(40 \%)$ patients due to invasion of the adjacent vascular structures or hemorrhage. During the post-operative period, 2 patients $(13.3 \%)$ developed grade A pancreas fistula and spontaneously closed during follow-up. Mean follow-up period was 22 months (12-36). Operation related mortality wasn't seen. During the follow-up period, one (6.6\%) patient with ductal adenocarcinoma died due to distant metastasis at post-operative 14th month.
\end{abstract}

DISCUSSION AND CONCLUSION: Laparoscopic distal pancreatectomy seems a safe alternative to open surgery in patients with benign and malignant lesions of the pancreas body and tail.

Keywords: Pancreas, cancer, laparoscopy, distal pancreatectomy

\section{INTRODUCTION}

Removal of the left part of the portomesenteric vein of the pancreas tissue is described as distal pancreatectomy. Laparoscopic distal pancreatectomy (LDP) is commonly performed in malignant or potential malignant lesions, located in the pancreas body and tail (1). In pancreas lesions, laparoscopic interventions have started with staging and palliative procedures. First laparoscopic distal pancreatectomy was performed in 1994 (2). Laparoscopy is becoming preferred method 
especially in distal lesions with the advantage of does not require any reconstructive procedure contrarily to head lesions (3). On the other hand, minimal invasive resections are still limited due to retroperitoneal localization of pancreas, close adjacency to major vascular structures and the need for experienced surgical team in advance Laparoscopy. Approximately $20 \%$ of the distal pancreatectomies are performed laparoscopically in USA in $2015(4,5)$. Performing distal pancreatectomy with laparoscopic method provides significant advantages of less morbidity, shorter hospitalization, less wound problems and clear imaging of the anatomic structures during surgery (6).

In this study, we present surgery and follow-up results of patients undergoing LDP.

\section{MATERIAL and METHODS}

Data from 15 patients who underwent laparoscopic distal pancreatectomy for pancreas tumor between January 2014 and January 2015 was retrospectively assessed. All procedures performed in studies involving human participants were in accordance with the ethical standards of the 1964 Helsinki declaration and its later amendments or comparable ethical standards. Informed consent was obtained from all individual participants included in the study.

Demographic data, body mass index (BMI), comorbidity, the American Society of Anesthesiologist (ASA) score, the tumor diameter, operation time, intraoperative blood loss, postoperative morbidity and mortality, hospitalization time, histopathological diagnosis and follow-up time were recorded.

Preoperative evaluation of lesions and their relationship with adjacent vascular structures was performed by ultrasonography (USG), computed tomography (CT) and magnetic resonance imaging (MRI). Endoscopic ultrasonography is performed if necessary.

Following incision from the umbilicus, pneumoperitoneum $(12 \mathrm{mmHg})$ was created with carbon dioxide. $30^{\circ}$ telescope was used for the operations. Intraabdominal region was explored. 3 or $4,5 \mathrm{~mm}$ trochars was placed into abdomen under camera vision. Gastrocolic ligament was opened using high-energy instruments (Harmonic scissors, Ethicon, USA) along the major curvature of the stomach. Retroperitoneum was dissected in inferior side of the pancreas and pancreas was elevated with blunt and sharp dissections. The splenic artery and vein was revealed. Superior side of the pancreas was dissected and the pancreas was totally suspended. After the pancreas body and tail sections were completely mobilized, pancreas was divided by using an endoscopic linear stapler (EchelonFlex ${ }^{\mathrm{TM}}$, Ethicon, USA) min. $2 \mathrm{~cm}$ away from the tumoral lesion. Splenic artery and vein were taken into the stapler in splenectomy performed cases. Kimura technique was applied by the pancreatic minor vein and the arteries were clipped and cut in spleen preserved ones. Specimen was placed into an organ bag (EndobagTM, Covidien, USA) and was taken out via pfannenstiel miniincision. Fibrin tissue sealent (Tissel ${ }^{\mathrm{TM}}$, Baxter) was sprayed to pancreatic stapling line and an adsorbent drain was placed into the pancreas stump.

Drain amylase detected 3fold higher than simultaneous serum amylase is accepted as pancratic fistula based on the criteria defined by the international pancreatic fistula group (The International Study Group of Pancreatic Fistula (ISGPF) (7).

\section{Statistical Analysis}

Statistical analyses were performed using Statistical Package for Social Sciences (SPSS) for Windows version 21.0 (SPSS. Inc., Chicago, IL) software. Mean \pm standard deviation for parametric values and median values (minimum-maximum) for non-parametric data were expressed.

\section{RESULTS}

Patient demographics, BMI, comorbidity, tumor diameter and location and ASA scores are presented in Table 1. Three patients had hypertension (20\%), two patients had type 2 diabetes mellitus (13.3\%) and three patients (20\%) had both. Spleen was preserved in four patients with Kimura technique. The median tumor diameter was $40.4 \mathrm{~mm}(30-70 \mathrm{~mm})$. Tumor localization was observed at similar rates in the pancreas body and tail $(60 \%$ and $40 \%$, respectively).

\section{Table 1: Demographic data of the} patients and disease morphology 


$\begin{array}{lc}\begin{array}{l}\text { Gender } \\ \text { F/M }\end{array} & 8(53.3 \%) / 7(46.6 \%) \\ \text { Age (years) } & 60.4 \pm 9.82 \\ \text { BMI }\left(\mathbf{k g} / \mathbf{m}^{2}\right) & 29.6 \pm 6.22 \\ \text { Comorbidity } & 8(53.3 \%) \\ \text { Tumor diameter }(\mathbf{m m}) & 40.4(30-70) \\ \text { Tumor localization } & \\ \text { Bail } & 9(60 \%) \\ \text { ASA } & 6(40 \%) \\ \text { 1/2/3 } & 4(26.6 \%) / 10(66.6 \%) \\ \end{array}$

BMI: Body mass index

Conversion laparotomy was necessary in six patients $(40 \%)$. The conversion reason was invasion of the adjacent vascular structures in two patients and hemorrhage was in four patients (Table 2). The mean duration of laparoscopic operations was 144.3 minutes (160-210). During the postoperative follow up period, acute neurologic infraction was seen in one $(6.66 \%)$ patient and treated with medical treatment. Pancreatic fistula was detected in two (13.3\%) patients, both was Grade A. An approximate daily drainage was $50-100 \mathrm{cc}$. First patient was discharged at postoperative $11^{\text {th }}$ days and the second was $15^{\text {th }}$. Both patients were discharged with drains. The patients were requested to record daily drainage amounts and checked every week. The fistulas were closed on postoperative $30^{\text {th }}$ and $45^{\text {th }}$ days. No mortality occurred during the postoperative period.

The final histopathologic examination revealed ductal adenocarcinoma in five cases (33.3\%), mucinous cystadenoma in eight cases $(53.3 \%)$ and serous cystadenoma in two cases $(13.3 \%)$ (Table 3). Surgical margins were negative in all malignant patients and they underwent adjuvant chemotherapy program. The mean number of the lymph nodes was 6 (212).

\section{Table 2: Operative and post operative follow up data}

n

$\begin{array}{ll}\text { Operationtechnique } & \\ \text { Laparoscopy } & 9(60 \%) \\ \text { Conversion } & 6(40 \%)\end{array}$

Operation time (minutes)

$144.3(110-210)$

Morbidity

$3(20 \%)$

Mortality

Pankreatic Fistula

$2(13.3 \%)$

Hospital stay (days)

$6.8(4-15)$

Follow-up time (month)

$22(12-36)$

The mean duration of follow-up was 22 months (12-36 months). In long term follow up, one patient $(6.6 \%)$ died due to distant metastasis at the postoperative $14^{\text {th }}$ month. No metastasis or local recurrence was detected in the other patients (Table 2).

Table 3: Histopathologic examination of the specimens

\begin{tabular}{lc}
\hline & $\mathbf{n}$ \\
\hline Pathological diagnosis & \\
Ductal Adenocarcinoma & $5(33.3 \%)$ \\
Mucinous Cystadenoma & $8(53.3 \%)$ \\
Serous Cystadenoma & $2(13.3 \%)$ \\
Lymph Node & $6(2-12)$ \\
\hline
\end{tabular}

\section{DISCUSSION}

Pancreatic ductal adenocarcinoma is the $5^{\text {th }}$ leading cause of mortality associated with cancer and the rate of 5-year survival is only $6 \%$ after diagnosis (8). In case of pancreas cancer, the only potential curative treatment choice is surgery. Approximately $20 \%$ of the pancreas cancers are located in the body and tail. Presence of non-specific symptoms at early stages of disease leads to late diagnosis and at the time of diagnosis, $80 \%$ of the patients have unresectable disease due to metastasis or major vascular invasion $(9,10)$.

Pancreatic cystic tumors which have premalignant potantial should be resected to avoid cancer progression. The prevalence of pancreatic cystic tumors is $2.5 \%$, which increases with age and reaches $10 \%$ after $7^{\text {th }}$ decade (11). They are divided into subgroups as 
serous cystadenoma (SCA), mucinous cystic neoplasia (MCN), intraductal papillary mucinous neoplasia (IPMN) and solid pseudopapillary neoplasia (SPN) with the prevalence rates of IPMN (38\%), MCN (23\%) and SCA (16\%) (12). The malignancy risk was approximately $17 \%$ for MCN, $45 \%$ for IPMN located in the main ductus, and $<1 \%$ for SCA (11). Because they have malignancy potential, surgical resection is important for MCN and IPMN (13). Because small-diameter serous cystadenomas have low malignancy potantial, they can be followed up. On the other hand, serous cystadenomas with large diamater should be resected (12). Eight patients were operated for mucinous cystadenoma in our study.

In patients with suspected malignancy, regional lymph nodes should also be dissected along with distal pancreatectomy. Some authors suggest splenectomy in these cases to be able to resect adequate lymph node dissection. On the other hand, growing interest in splenic immunological function has led surgeons to perform distal pancreatectomy with spleen preservation. This can be performed either by preserving the splenic vessels as in Kimura technique or by resecting them as in Warshaw's technique relying on the blood inflow through the short gastric vessels. Lymph nodes should be dissected along the splenic vessels in Kimura technique applied patients. Warshaw's technique has advantages of lower intraoperative blood loss, shorter operative time, reduced hospital stay and a lower complication rate. In cases of distal pancreatectomy with or without splenectomy, no significant differences were detected with respect to major complications ie, pancreatic fistula with similar rates (14). However, in patients with preserved spleen, perioperative infection and hospitalization durations were reported to be reduced (14). Spleen was preserved in our 4 patients. Splenectomy was performed in the other ones due to close adjacency of the lesion to spleen hilus or bleeding from the spleen capsule.

Laparoscopy has well known advantages to open surgery and localization of the pancreatic lesion, malignancy and tumor diameter are not limiting factors for laparoscopic procedures (15). Operation times of laparoscopic distal pancreatectomy were reported shorter, equal or longer when compared to open surgery (15). Variability in operation times was explained by surgical experience (16). The mean operation time was 144.3 minutes (60-210) in our cases, which was consistent with the literature data (15). The conversion rate was reported to be $0-33 \%$ in literature (17). Obesity, adhesions, large and proximally located tumors, difficulty in localization of intraoperative lesions, hemorrhage or margin positivity were the reported reasons to conversion. Local fibrosis and inflammation can reduce tumor mobilization in case of malignant lesions, located in the pancreas tail and complicate dissection in this region (18). We observed a conversion rate of $40 \%$ in our trial. Conversion reasons were hemorrhage or invasion of adjacent vascular structures in our cases.

Following laparoscopic distal pancreatectomy, morbidity was reported at an approximate rate of $26-40 \%$ (19). In our study, we detected a morbidity rate of $20 \%$. Pancreas fistula occurs as a result of the failure in closure of the pancreatic ductus. Fistula rates have been reported distinctly between studies due to differences in fistula definition and classification. Some studies were accepted fistula in only intervention required cases. Thus, the International Study Group on Pancreatic Fistula (ISGPF) made a definition and classification (7). Pancreatic fistula rates were reported to be similar following laparoscopy and open surgery, ranging between $13 \%$ and $50 \%(19,20)$. There were no differences between suture and stapler use in pancreas stump in some studies (21). However, the others reported potantial effect of stapler using in preserving fistula formation especially $2.5-\mathrm{mm}$ stapler than 4.5-mm (21). In our cases, we used stapler routinely for dividing the pancreas however fistula developed in 2 patients. In case of fistula occurrence, up to $90 \%$ of the patients can achieve recovery with conservative approaches as in cases (22). Patients, who are refractory to medical treatment, may require radiologic drainage, and they may rarely need surgery (22). In some studies, somatostatin analogues were claimed to prevent fistula development $(22,23)$. Somatostatin analogues were particularly recommended for patients with soft pancreas tissue, small-diameter pancreatic ductus and marked intraoperative 
blood loss (23).

Hospitalization in laparoscopic resected patients is shorter in most literature and was reported as 6-27 vs. 5-22 days following open and laparoscopic resections, respectively $(15,17,19)$. In our trial, mean hospitalization time was 6.8 days.

Surgical outcome of LDP is similar to open. Positive surgical margins were reported as $0-26 \%$ vs. $0-27 \%$, dissected lymph nodes were 6-14 vs. 9-17, primary tumour diameters were $2.5-3.3$ vs $3-7.7 \mathrm{~cm}$. spesimen lengths were $7.7-9.4$ vs. $9.4-10 \mathrm{~cm}$. in LDP and open distal pancreatectomy respectively. $(15,19,20)$. Various reports had showed that small tumour size is a selection bias for laparoscopic procedures $(19,20)$. In our patients; mean tumour diameter is 40.4 (30-70) $\mathrm{mm}$ and mean count of dissected lymph nodes is 6 (2-12). Long-term oncologic outcomes of LDP in malignant cases is also similar to open. Average 3 years survival was reported as $36 \%$ and a median survival time was $15-23$ months (24). The average follow up period is 22 months (1236 ) in our study. Only one patient with ductal adeno carninoma had died in post-operative $14^{\text {th }}$ month due to distant metastasis occured after surgery. The other patients under follow up period are still disease free.

Mortality has been reported as $<1 \%$ in LDP cases $(19,20)$. No operation related mortality was observed in our patients.

\section{CONCLUSION}

Having experience on advanced laparoscopic methods is determinant in laparoscopic distal pancreatectomy. LDP is adopted as an effective and safe, standard procedure in benign lesions. However, in malignant patients, the place of laparoscopy will be clearer upon prospective randomised studies.

Conflict of Interest: No conflict of interest was declared by the authors.

Financial Disclosure: The authors declared that this study has received no financial support.

\section{REFERENCES}

1. Lee MK, Vollmer CM. The current state of minimally invasive distal pancreatectomy. Curr Surg Reports 2013; 1: 106-13.
2. Gagner M, Pomp A. Laparoscopic pyloruspreserving pancreato duodenectomy. Surg Endosc 1994; 8: 408-410.

3. Eom BW, Jang JY, Lee SE, Han HS, Yoon YS, Kim SW. Clinical outcomes compared between laparoscopic and open distal pancreatectomy. Surg Endosc 2008; 22: 1334-8.

4. Casadei R, Ricci C, D'Ambra M, et al. Laparoscopic versus open distal pancreatectomy in pancreatic tumours: a case-control study. Updates Surg 2010; 62: 171-4.

5. Kooby DA, Gillespie T, Bentrem D, et al. Leftsided pancreatectomy: a multicenter comparison of laparoscopic and open approaches. Ann Surg 2008; 248: 438-43.

6. Fisher SB, Kooby DA. Laparoscopic pancreatectomy for malignancy. J Surg Oncol 2013; 107: 39-50.

7. Pratt WB, Maithel SK, Vanounou $T$, et al.Clinical and economic validation of the international study group of pancreatic fistula (ISGPF) classification scheme. Ann Surg 2007; 245: 443-51.

8. Siegel RL, Miller KD, Jemal A. Cancer statistics. CACancer J Clin2015;65:5-29.

9. Werner J, Combs SE, Springfield C, Hartwig W, Hackert T, Büchler MW. Advanced-stage pancreatic cancer: therapy options. Nat Rev ClinOncol2013;10:323-33.

10. Tempero MA, Malafa MP, Behrman SW, et al. Pancreatic adenocarcinoma, version 2.2014: NCCN guidelines. J Natl Compr Cancer Netw2014;12:1083-93.

11. Farrell JJ, Fernández-del Castillo C. Pancreatic cystic neoplasms: management and unanswered questions. Gastroenterology 2013; 144: 130315.

12. Valsangkar NP, Morales-Oyarvide V, Thayer $\mathrm{SP}$, et al. 851 resected cystic tumors of the pancreas: a 33-year experience at the Massachusetts General Hospital. Surgery 2012; 152: S4-12.

13. Tanaka M, Fernández-Del Castillo C, Adsay $\mathrm{V}$, et al: International consensus guidelines 2012 for the management of IPMN and MCN of the pancreas. Pancreatology 2012; 12: 183-97.

14. Fernández-Cruz L, Orduña D, Cesar-Borges G, López-Boado MA. Distal pancreatectomy: enbloc splenectomy vs spleen-preserving pancreatectomy. HPB (Oxford) 2005;7:93-8.

15. Limongelli P, Belli A, Russo G, et al. Laparoscopic and open surgical treatment of left-sided pancreatic lesions: clinical outcomes and cost-effectiveness analysis. Surg Endosc 2012; 26:1830-6.

16. Kneuertz PJ, Patel SH, Chu CK, Fisher SB, Maithel SK, Sarmiento JM, et al. Laparoscopic distal pancreatectomy: trends and lessons learned through an 11-year experience. J Am Coll Surg 2012; 215: 167-176.

17. Liang S, Hameed U, Jayaraman S. Laparoscopic pancreatectomy: indications and outcomes. World Gastroenterol 2014; 20: 14246-54.

18. De Rooij T, Jilesen AP, Boerma D, et al. A nationwide comparison of laparoscopic and open distal pancreatectomy for benign and 
malignant disease. J Am Coll Surg 2015;220:263-270.

19. DiNorcia J, Schrope BA, Lee MK, Reavey PL, Rosen SJ, Lee JA, et al. Laparoscopic distal pancreatectomy offers shorter hospital stays with fewer complications. J Gastrointest Surg 2010; 14: 1804-1812.

20. Finan KR, Cannon EE, Kim EJ, Wesley MM, Arnoletti PJ, Heslin MJ, et al. Laparoscopic and open distal pancreatectomy: a comparison of outcomes. Am Surg 2009; 75: 671-679.

21. Zhou W, Lv R, Wang X, et al. Stapler vs suture closure of pancreatic remnant after distal pancreatectomy: a meta-analysis. Am J Surg
2010; 200: 529-36.

22. Callery MP, Pratt WB, Vollmer CM Jr Prevention and management of pancreatic fistula. J Gastrointest Surg 2009;13:163-73.

23. McMillan MT, Vollmer CM Jr. Predictive factors for pancreatic fistula following pancreatectomy. Langenbecks Arch Surg. 2014;399:811-24.

24. Marangos IP, Buanes T, Røsok BI, Kazaryan AM, Rosseland AR, Grzyb K et al. Laparoscopic resection of exocrine carcinoma in central and distal pancreas results in a high rate of radical resections and long postoperative survival. Surgery 2012; 151: 717-723. 